\title{
Editorial
}

\section{Mayores puntajes de síntomas en escala "Menopause Rating Scale" (MRS) asocian con mayor riesgo de Depresión Mayor.}

El manejo clínico de las mujeres en edad de climaterio se ha ido perfeccionando gracias a los modelos estadísticos que nos han hecho salir del antiguo estrecho concepto de catalogar a la mujer como sintomática debido a la menopausia, por tener tan solo bochornos, abriéndonos a la realidad de muchos otros síntomas con importancia clínica: síntomas somáticos, psicológicos y urogenitales. La escala MRS ha sido validada en idioma español para cuantificar la autovaloración subjetiva de síntomas asociados al climaterio.

Aunque probablemente el síntoma más prevalente consiste en dolores músculo esqueléticos, los psicológicos destacan por afectar de forma importante la calidad de vida y el desempeño personal. Aunque en la etapa del climaterio hay muchos factores biopsicosociales tales como incertidumbres, cambios de roles, de carga de trabajo personal, de relaciones interpersonales, todas potencialmente causantes de estrés, ansiedad, angustia, irritablidad e insomnio, estos síntomas tienen también un sustrato hormonodependiente. Surge entonces una pregunta de investigación, si acaso la presencia de otros síntomas climatéricos modifica la prevalencia de síntomas psicológicos y en particular de depresión.

El grupo de Hernández-Muñoz (1) se hace cargo del análisis de la relación entre el puntaje de síntomas registrados mediante la escala MRS y la aplicación del inventario de Depresión de Beck para detectar depresión mayor, en una población de 252 mujeres en posmenopausia reciente, una muestra con poder estadístico para representar a 10,854 consultantes anuales del Servicio de Salud de Jalisco, México.

Nos muestra dos realidades que antes no parecían tan evidentes: la tasa de portadoras de Trastorno Depresivo Mayor (TDM) resultó ser casi el doble que la prevalencia previamente conocida de $21,3 \%$ en su propia población, y lo más útil para la práctica clínica, mayores puntajes en los dominios psicológico y urogenital, asociaron con un mayor riesgo de depresión mayor, de tal manera que tener 7,2 $\pm 3,8$ puntos o más en el dominio psicológico de la escala MRS elevó el riesgo de Depresión Mayor en 12,5 veces, mientras que tener 3,6 $\pm 2,7$ puntos en el urogenital elevó el mismo riesgo 3,29 veces. El dominio somático incrementó el riesgo de TDM en 2,96 veces si supera $8,5 \pm 3,8$ puntos.

En mujeres sin TDM, el puntaje promedio en el dominio somático fue $4,4 \pm 3,6$,en el dominio psicológico $2,9 \pm 2,7$ y en el urogenital $1,4 \pm 1,8$.

La prevalencia de TDM tuvo relación con la severidad de la afectación en la escala MRS utilizando criterios previamente reportados $(2,3)$.

Este trabajo aporta datos valiosos que agregan confianza al uso de la escala MRS para orientar la detección de Depresión Mayor. Los puntos de corte aplicados para establecer los grados de afectación de cada ítem y de cada dominio en la escala MRS, en términos de "leve", "moderado" o "severo", que provienen del modelamiento estadístico original, no deben ser confundidos con los puntos de corte que se aplicaron en las Orientaciones Técnicas para el Manejo Integral de la Mujer en Edad del Climaterio aprobados por el Ministerio de Salud de Chile el 2014 para su uso amplio en la práctica clínica a nive nacional (4), puesto que estos son criterios de intervención y generalmente coinciden con los tramos altos de afectación moderada en los diversos dominios. En esa guía clínica, se recomienda que a toda mujer con 6 o más puntos en el dominio psicológico, se aplique un cuestionario adicional para detección de Depresión Mayor, con la finalidad de trazar un plan de acción que considere intervenciones 
farmacológicas buscando sinergia entre fármacos antidepresivos y terapia de reposición hormonal.

Existe evidencia científica de plausibilidad biológica, que relaciona cambios en la actividad neuronal serotoninérgica, dopaminérgica, colinérgica, noradrenérgica (4) y gabaérgica en mujeres insuficientes de esteroides gonadales. Este estudio no tiene poder estadístico para evaluar la relación de prevalencia de uso de THM y depresión, no obstante, existen evidencias de respuesta favorable a la reposición hormonal en estudios experimentales (59), también frente al uso de antidepresivos, especialmente cuando se usan inhibidores selectivos de recaptación de serotonina (ISRS) o duales, y más aún cuando el enfoque clínico se orienta a obtener el mejor provecho de ambos recursos de tratamiento combinados, además del aporte del equipo de salud capacitado para realizar análisis biopsicosocial en cada caso individual, identificar los factores productores de estrés dominantes y las necesidades de mejoramiento adaptativo.

No cabe duda que esta nueva pieza de evidencia sirve al clínico para reforzar el uso de la escala MRS, como instrumento de apoyo a la anamnesis, que posee la capacidad para ayudar a jerarquizar los problemas autoreportados de acuerdo a su intensidad, e identificar entre ellos la posibilidad de presentar depresión mayor, para luego aplicar las pautas de manejo que se han ido validando. La diferencia entre la prevalencia supuesta y la observada, que fue mucho mayor, debieran motivar a los clínicos a asumir la pesquisa activa de depresión en toda mujer con puntajes moderados o altos en la escala MRS.

\section{Higher symptom scores on the "Menopause Rating Scale" (MRS) scale are associated with a higher risk of Major Depression.}

The clinical management of women of climacteric age has been perfected thanks to the statistical models that have led us out of the old narrow concept of cataloging women as symptomatic due to menopause, for having only hot flashes, opening ourselves to reality of many other symptoms of clinical importance: somatic, psychological and urogenital symptoms. The MRS scale has been validated in Spanish to quantify the subjective self-assessment of symptoms associated with climacteric.
Although probably the most prevalent symptom consists of skeletal muscle pain, the psychological ones stand out because they significantly affect the quality of life and personal performance. Despite of the climacteric stage there are many biopsychosocial factors such as uncertainties, role changes, personal workload, interpersonal relationships, all potentially causing stress, anxiety, distress, irritability and insomnia, these symptoms also have a hormonedependent substrate. A research question then arises, if the presence of other climacteric symptoms changes the prevalence of psychological symptoms and in particular depression.

The Hernández-Muñoz group (1) analyzed the relationship between the symptom score recorded using the MRS scale and the application of the Beck Depression inventory to detect major depression, in a population of 252 women in recent postmenopause, a sample with statistical power to represent 10,854 annual consultants of the Jalisco Health Service, Mexico.

It shows two realities that did not seem so obvious before: the rate of carriers of Major Depressive Disorder (MDD) was almost double that of the previously known prevalence of $21.3 \%$ in their own population, and most useful for clinical practice, higher scores in the psychological and urogenital domains, associated with a higher risk of major depression, such that having $7.2 \pm 3.8$ points or more in the psychological domain of the MRS scale raised the risk of Major Depression by 12,5 times, while having $3.6 \pm 2.7$ points in the urogenital raised the same risk 3.29 times. The somatic domain increased the risk of MDD by 2.96 times if it exceeds $8.5 \pm 3.8$ points.

In women without MDD, the average score in the somatic domain was $4.4 \pm 3.6$, in the psychological domain $2.9 \pm 2.7$ and in the urogenital $1.4 \pm 1.8$.

The prevalence of MDD was related to the severity of the involvement in the MRS scale using previously reported criteria $(2,3)$.

This work provides valuable data that adds confidence to the use of the MRS scale to guide the detection of Major Depression and the cut-off points applied to establish the degrees of affectation of each item and of each domain in the MRS scale. The "mild", "moderate" or "severe" grades come from the original 
statistical model. They should not be confused with the cut-off points that were applied in the Technical Guidelines for the Comprehensive Management of Women in Climateric Age approved by the Ministry of Health of Chile 2014 for the country-wide use in clinical practice (4), since these are intervention criteria, and generally coincide with scores of moderate and severe involvement. In this clinical guideline, it is recommended that for every woman with 6 or more points in the psychological domain, an additional questionnaire for detection of Major Depression be applied, in order to draw up an action plan that considers pharmacological interventions seeking synergy between antidepressant drugs and hormone replacement therapy.

There is scientific evidence of biological plausibility, which relates changes in serotonergic, dopaminergic, cholinergic, noradrenergic (4) and gabaergic neuronal activity in insufficient women of gonadal steroids. This study has no statistical power to evaluate the prevalence ratio of THM use and depression, however, there is evidence of a favorable response to hormonal replacement in experimental studies (5-9), also using antidepressants, especially with selective inhibitors of serotonin reuptake (SSRIs) or duals, and even more so when the clinical approach is oriented to obtain the best benefit from both combined treatment resources, in addition to the contribution of the trained health team to perform biopsychosocial analysis in each individual case, identify the dominant stress producing factors and adaptive improvement needs.

There is no doubt that this new piece of evidence serves the clinician to reinforce the use of the MRS scale, as an anamnesis support instrument, which has the capacity to help rank self-reported problems according to their intensity, and identify among them the possibility of presenting major depression, to then apply the management guidelines that have been validated. The difference between the assumed and the observed prevalence, which was much greater, should motivate clinicians to assume active depression screening in all women with moderate or high scores on the MRS scale.

\section{Dr. Sergio Brantes Glavic Profesor Adjunto Campus Oriente Universidad de Chile}

\section{Bibliografía}

(1) Adrián Enrique Hernández-Muñoz, Ana Méndez-Magaña, Melva Guadalupe HerreraGodina, Ana Lilia Fletes-Rayas, Carlos Enrique Cabrera-Pivaral, Beatriz Adriana Vázquez-Pérez. Riesgo para el desarrollo de Trastorno Depresivo Mayor al existir alteraciones en la sintomatología menopáusica en mujeres de Guadalajara, Jalisco. (En el presente número de Revista SOCHEG)

(2) DeCherney A, Nathan L, Laufer N, Roman A. Menopausia y Posmenopausia. En: Diagnóstico y tratamientos ginecoobstétricos. Barcelona, España: McGraw-Hill; 2014, 963.

(3) Chedraui P, Aguirre W, Hidalgo L, Fayad L. Assessing menopausal symptoms among healthy middle aged women with the Menopause Rating Scale. Maturitas. 2007; 57(3):271-8.

(4) Orientaciones Técnicas Minsal para Manejo de la Mujer en Edad del Climaterio, 2014.

(5) McEwen B. Estrogen Effects on the Brain: Much More than Sex. Karger Gazette, 66, Hormones, feb 2013

(6) Gordon JL, Rubinow DR, Eisenlohr-Moul TA, Xia K, Schmidt PJ, Girdler SS. . Efficacy of Transdermal Estradiol and Micronized Progesterone in the Prevention of Depressive Symptoms in the Menopause Transition: A Randomized Clinical Trial. JAMA Psychiatry. 2018 Feb 1;75(2):149157.

(7) Kulkarni J, Gavrilidis E, Thomas N, Hudaib AR, Worsley R, Thew C, Bleeker C, Gurvich C. Tibolone improves depression in women through the menopause transition: A doubleblind randomized controlled trial of adjunctive tibolone. J Affect Disord. 2018 Aug 15;236:88-92.

(8) Schmidt PJ, Ben Dor R, Martinez PE, Guerrieri GM, Harsh VL, Thompson K, Koziol DE, Nieman LK, Rubinow DR. Effects of Estradiol Withdrawal on Mood in Women With Past Perimenopausal Depression: A Randomized Clinical Trial. JAMA Psychiatry. 2015 Jul;72(7):714-26.

(9) Rasgon NL, Dunkin J, Fairbanks L, Altshuler LL, Troung C, Elman S, Wroolie TE, Brunhuber MV, Rapkin A. Estrogen and 
response to sertraline in postmenopausal women with major depressive disorder: a pilot study. J Psychiatr Res. 2007 AprJun;41(3-4):338-43. 